\title{
Promises, Promises? Or Restoration and Renaissance? Fifteen Brutal Years for School Libraries in British Columbia
}

\author{
Moira Ekdahl \\ University Hill Secondary School, Canada
}

In consultation with Heather Daly, President, and Grahame Rainey, Treasurer
British Columbia Teacher-Librarians'Association, Canada

\begin{abstract}
British Columbia teachers, through the offices of the BC Teachers' Federation (BCTF) and often through their own time on the picket lines, have fought for fifteen years to get back the negotiated language that contractually defined the working conditions of teachers, including specialist or nonenrolling teachers such as teacher-librarians. This paper documents the struggles that took the case all the way to the Supreme Court of Canada where, in November of 2016, in just minutes, the teachers' rights were affirmed and the BC Liberal government's actions in stripping the negotiated contract language were determined to be illegal. Staffing lost was to be restored. For teacher-librarians, easily the hardest hit teacher group, the decision seemed to offer a breath-taking relief after years of progressively deeper cuts. At the time of writing, believing in the imminent full restoration of staffing to re-define the work of teacher-librarians and in a glorious re-birth of the place of the school library in public education in BC appears to be unrealistic.
\end{abstract}

\section{Keywords: British Columbia, BCTF, Teacher-Librarians, Supreme Court of Canada, Restoration, Staffing, Ratios, Non-Enrolling}

\section{INTRODUCTION}

The story you are about to be told has all the twists and turns of a docudrama. It begins with a powerful government and the handiwork of an individual in the Cabinet ranks, one who would rise to the top to further complicate events. It features antagonists who specialized in lies told, spare-no-expense courtroom proceedings won and lost, and scurrilous and underhanded trickery; they were facing off against protagonists whose dogged determination and weeks of walking to seek what is right for public education in British Columbia eventually brought them into the light.

Amongst those who walked for the rights of all, there was a small group, more likely to be women than men, who marched because there was something very wrong with larger class sizes and the ways classrooms were composed that exacerbated the workload of their teacher colleagues. Their own place in schools and in relation to learners had been summarily stripped from the contract too, though one was less likely to hear the case for their return, there being fewer of them; there was supposed to be 1 of them for every 702 students, or a pro-rating of this. During the ensuing fifteen years, $37 \%$ were "disappeared." One might have been tempted to establish a stand on the street outside one's school and read aloud from that Martin Niemöller poem, "First they came for the Socialists ..."

As the years rolled on, this small group - the province's teacher-librarians, part of a larger subgroup called non-enrolling or learning specialist teachers, similarly stripped of their ratios-was simply smaller and the job they did had been largely transformed, reduced, deemed expendable. On the day the light came on again in November 2016, they were joyful and optimistic that the positions lost would be restored and the work they so passionately provided re-valued. In the school districts where their positions had been eliminated or more heavily cut than others, there was to be a rush to find qualified (or qualifying) replacements to restore the lost ones. But this was not to be the case everywhere. 


\section{BC'S POLITICAL CONTEXT FOR TEACHING}

Former President of the British Columbia Teachers' Federation (BCTF) Susan Lambert, who had previously been a school-based teacher-librarian, begins her submission to BC Studies: The British Columbian Quarterly (March 2017) with direct reference to American politics:

Watching the institutions of democracy crumble in the United States has sparked reflection and introspection in Canadians. The story of the British Columbia Teachers' Federation's (BCTF) struggle against BC's provincial Liberals is situated in this global context. Public education, collective bargaining and unions, the law and judicial system, and government and politics are four institutions of democracy that play pivotal roles in this story. (p. 2)

A recent article in The New York Times (Dan Levin, Jan 13, 2017) officially launched the notion of the province of British Columbia as "the wild west." In its own mind, British Columbia is Canada's equivalent to California; it is often referred to as "Hollywood North" and we refer to ourselves in selfdeprecating terms as "Lotus Land." This has everything to do with lifestyle, film-making, climate, andyes-left-leaning or "small l" liberal politics:

Critics of the premier and her governing party, the conservative British Columbia Liberal Party, say the provincial government has been transformed into a lucrative business, dominated by special interests that trade donations for political favors, undermining Canada's reputation for functional, consensus-driven democracy. (n.p.)

Events of scandalous proportion have roiled the surface waters, particularly since the transformation of the present Premier from her political start as the province's Education Minister, but nothing has really boiled over and stuck. This most recent designation of "wild west" alludes to party finances, including political contributions, an "unabashedly cozy relationship between private interests and government officials in the province." In this case, the province's Attorney General reassured the public that the province's standards "should give the public confidence in the electoral system." In the recent May 2017 election, that same Attorney General lost her seat and the Premier has tried to spin the lukewarm "victory" (the barest of supposed minority government status) for her party into a claim that the outcome is evidence that the voters want her Liberals to cooperate with other political parties. Here in Lotus Land, it means the unthinkable reality that most voters did not want her government and she would need to work in tandem with the three-seated Green Party, which has decided against such a partnership.

Flashback 15 years. The same main character is seen in her role as Education Minister to the newly elected BC Liberal majority government overseeing the first of many drastic measures to curb education spending. In 2001, there had been a landslide "Liberal" victory and the major opposing party only retained two seats. Immediately, this government announced generous personal and corporate tax cuts, as well as intentions to cut government spending. The effects of this last promise have been felt and bitterly fought over the last 15 years. Social spending - health care, welfare, support for people with disabilities, housing, children living in poverty or in care, education-was sacrificed and this continued as chronic underfunding in all of these portfolios.

Despite promises they would not, the $\mathrm{BC}$ Liberals tore up negotiated provisions - collective agreement language bargained to provide better working and learning conditions - in the health care and teachers' contracts in an act of what Madam Justice Susan Griffin called "legislative interference" in the 2011 BC Supreme Court decision (BCTF v BC, 2011, in Lambert), what Lambert calls "legislative vandalism [that] devastated teachers" (p.3), and what Vaughn Palmer, a reporter for The Vancouver Sun, called a "legislative double cross that reverberates to the current day" (November 2016, in Lambert, p.3). By the fall of 2016, forty thousand teachers could say they had fought hard and worked together, alongside their Federation leadership. They had patiently awaited the end of a prolonged legal and political process, including walking the picket lines for "class size, class composition, and ratios for nonenrolling teachers." A world-class education system was fighting to retain its teachers' rights to have a say about their own working conditions and the learning conditions of students against "a deliberate and concerted attack on a fundamental pillar of democracy [during which the Premier] deliberately set out to 
mine public education budgets and support competition from elite and religious private schools" (Lambert, p.8).

\section{THE DAY "EVERYTHING CHANGED”}

Patience paid off in November 2016, when the Supreme Court of Canada heard two hours of the case for and against the BCTF challenge to the Liberal government's successful appeal in 2015 of a 2014 BC Supreme Court decision that Bill 22 forcing teachers back to work was in fact unconstitutional. It took Canada's top court less than a half an hour to conclude that the BC Court of Appeal got it wrong in a case involving billions of public dollars. After hearing arguments and then a short recess, the Supreme Court of Canada came back and ruled in favour of the BC Teachers' Federation in an ongoing controversy that dates back to 2002. That's when the BC Liberal government tore up contracts with teachers and legislated class-size and classcomposition rules.

The Supreme Court of Canada decision repudiates a ruling last year by four of five justices on a BC Court of Appeal panel. They concluded that the BC Liberal government did not violate teachers' constitutional right to freedom of association by legislating class size and class composition a second time.

The only dissenting BC Court of Appeal justice at the time was Ian Donald. He agreed with trial judge Susan Griffin's ruling that this "unilateral nullification" of working conditions "substantially interfered" with the union's charter right to freedom of association. It came after the government's chief negotiator testified that the government's objective was to try to provoke a full-scale teachers' strike. (Smith, n.p.)

In just minutes, much to the surprise and delight of BC teachers, the Justices of the Supreme Court of Canada had returned a 7-2 decision to reinstate the BC Supreme Court decision to set the Liberal government and the Teachers' Federation on the path of restoring the contract language including the provisions about class size, class composition, and ratios for specialist teachers (Zussman, "Timeline" CBC News, Nov 10, 2016). They agreed with Ian Donald's legal analysis of Justice Griffin's 2014 decision.

For a while after November 2016, teachers were able to breathe and smile again, hopeful that there would now be a place for them in the process of re-focusing and refunding education. Talk of restoration of staffing - along with a new curriculum in which inquiry figures prominently - held promise of a renaissance for teacher-librarians who foresaw a new place for the school library in the learning equation of BC schools facing a new curriculum with new demands for exactly what they knew how to do. There was and remains a hesitancy; the same government headed by the same Premier who had started it all was not easily trusted to protect public education as a democratic institution; she "immediately and shamelessly, ... with appalling dishonesty ... announced she was pleased by the decision... 'If it costs more money, that's a good thing in lots of ways because it's a good investment to put money into classrooms and our kids"' (Clark in Lambert, p.8).

Observations are readily drawn from teachers' lived experience and are supported with additional insights from an article by Alex Hemingway, writing for the Canadian Centre of Policy Alternatives (CCPA), a highly respected "independent, non-partisan research institute concerned with issues of social, economic and environmental justice" (CCPA website). Hemingway's first major point, made before everything changed (November 2016), is, quite simply, that underfunding is a political choice.

It would be unreasonable to think that a public school system for the education of most of the province's students over 15 years of chronic underfunding would not have experienced the following:

- Increased class size and more complex classroom composition with less support from system staff assistants, non-enrolling teachers, appropriate resources, textbooks, and tools

- Districts invested in the "business" of education, including off-shore schooling and promotion of "Dogwood" certificates, marketing appeals for international students, and 
increased expectations for students to shop for and engage in online or distributed learning

- Increased accountability measures, more attention to school rankings, and teaching characterized by curriculum coverage, that is, shallow "covering" of hundreds of bulleted curriculum learning outcomes in the pressure to "teach to the test"

- Diminished morale in the face of acrimonious relations with the government and exacerbated by an inconvenienced public

- Costly legal measures to prolong the fight at the expense of teachers, their Federation, and $\mathrm{BC}$ taxpayers

- Ugly strategic interventions by the government in teacher politics and threats to school boards, including evidence of their attempt or intention to deliberately provoke a fullscale teachers' strike

- School closures, disjointed one-off funding announcements, assignment of impetus for which is often declining enrolment

- Parent-funded playgrounds, hot lunches, technology, fees for field trips, supplies, and transportation; teacher-purchased classroom supplies

- Persistent tensions, reflecting the fear of "Who's next?" in schools, exacerbated by the spring district budget process which easily produced circus-like annual trustees' meetings to which parents shepherded their children playing musical instruments to face off against groups in team jerseys, and the like.

\section{THE CASE FOR LIBERAL REINVESTMENT}

Hemingway argues we can more than afford to invest in public education. After fifteen years of chronic underfunding, there is now $25 \%$ less of the percentage of the province's Gross Domestic Product being allocated and $\$ 2$ billion has been cut from operating grants to schools. Benefits that are more likely to affect the wealthy and elite than others include "ill-advised" tax cuts such as facilities property and child care tax breaks as well as increased funding to private schools at a rate of three times what public schools have seen. This year, private schools will see funding of $\$ 358,000,000$. Other public school funding supplements for targeted populations, such as English Language Learners, are included in funding private schools, whether or not they have any ELL or other categories of designated students.

The BC Liberals have stripped capacity from public schools in other ways, as Hemingway has discovered, by downloading costs they essentially control, costs such as: medical premiums, employment insurance, the carbon tax, computer network upgrades, as well as salary and benefit increases for all staff; by withholding funds for capital and maintenance costs, forcing districts to defer facilities upgrades and maintenance; additionally, by implementing a new funding formula that assigns per student funding to districts, thus shifting the locus of blame from the government to school boards. And so on. Hemingway concludes that, in truth, "We can invest substantially more in public education in BC, but we-or rather our government and policymakers - choose not to. As we're beginning to see more clearly than ever, that choice has real consequences." The Premier points to recent PISA test results as a measure of the success of education initiatives in $\mathrm{BC}$; she appears not to see the dreadful sacrifices that have been made by educators in the face of years of de-professionalizing and demoralising working conditions to be able to teach students to the standards that are deeply held and the threat to the on-going sustainability of these efforts.

With each province being a separate educational jurisdiction, what is being spent on students in BC's public education system is readily measurable at $\$ 1000$ less per student than the Canadian average. This figure is further exacerbated by the reality that more than 120,000 children in BC live in poverty, a rate higher than the national average; in the words of Seth Klein and Iglika Ivanova, "No matter how you cut it, that's way too many for a rich province like BC." 


\section{THE UNION CASE FOR TEACHER-LIBRARIANS IN BC}

For teacher-librarians, the BCTF (2016) documents 38.7\% loss of FTEs province-wide over 15 years, with some districts more brutalized than others. No other teacher sector saw such extensive cuts. The collective agreement stipulates a minimum staffing level of $1 \mathrm{TL}$ for every 702 students, pro-rated; BCTF data indicates a provincial average of 1:647 in 2001, increased to 1:930 by 2015 .

Ann Ewbank (2015) undertook a case study of how the BC Teacher-Librarians' Association (BCTLA) Executive and its members work together and with the BC Teachers' Federation (BCTF) to advocate for strong and dynamic school library programs and qualified teacher-librarians in schools. The BCTLA is a provincial specialists' association (PSA) charged with providing professional development for its members, with promoting a positive and professional profile of teacher-librarians, and with helping its members in advocacy for the role.

Ewbank explored how working together and working within the union context ensured BC teacher-librarians were able to withstand the assault, "an uphill battle," and enabled the retention-at the time of the Supreme Court ruling - of over $60 \%$ of the teacher-librarian FTE in the province. Heather Daly (2015), BCTLA President, provided input to the Ewbank study prior to further FTE losses: "Given the global economic situation and related financial challenges, school librarians could have been completely eliminated. Without the union and its predominance in education matters, that 70 percent -30 percent statistic would probably be reversed."

Ewbank's conclusions provide a clear picture of the relationship of the BCTF to its PSAs. The $\mathrm{BCTF}$ recognizes the importance of its PSAs as channels for input to union direction and is responsive to their representations, including advocating for minimum ratios of staffing and against eliminating teacherlibrarian positions. The Executive of the BCTLA has strong leadership, close relationships, a "megaphone" role and is a centralized research and publication service for those like members of the BCTLA who complement these by engaging in a wide range of field-based advocacy activities. These members are clear and are stronger for their identity: "I am part of BCTLA" and "I AM THE BCTF."

\section{ADVOCACY AND THE LIVED EXPERIENCE OF THE YEARS UPHILL}

While advocacy is understood to be a key element of the work of a teacher-librarian, there is recognition that an uphill battle is exhausting. Ewbank's (2015) search of the relevant literature showed that teacher-librarians are very aware of the need for advocacy. In a survey she had previously conducted, more than half of the teacher-librarians surveyed indicated they were accustomed to threats of loss of their position or funding; while they knew advocacy was important, they were too busy.

There is no question that teacher morale in British Columbia had sunk to a new low. The intensification and de-professionalizing effects of the language strips and picket lines fragmented teaching staffs, creating on-going pressures for administrators to navigate competing and conflicting interests and for school districts to cut more and more classroom teaching and non-enrolling teacher positions each year to meet annual budget deficits; to add insult to injury, the government had been downloading costs to districts; in some districts, whole contingents of teacher-librarians disappeared or were cut incrementally and/or increasingly transformed to teachers enabling colleagues to have "prep blocks."

It is in circumstances like these that a professional association needs to become political, to "build influence" within the political structures of the teachers' organization, and to come together at the executive level to advocate for its members by addressing head-on the challenges of the ways in which their important place in the education equation is being eroded, even eliminated.

That, suggests one BC Teachers' Federation staff member, in response Ewbank's (2013) question about its role in relation to the PSAs, is the primary role of the Federation. "We encourage that and we expect them to come ... to us with advice ... [and] they expect us to support that through communications, through meetings between the table officers here and the Minister [of Education]" (p.3).

BCTLA Executive members, when interviewed, clarified the relationship: 
The BCTF is supportive of the PSA as long as we are here and as long as we make representations and ask for things that they have to respond to, because that's part of the mandate.

Because often the greater teachers' union has no understanding of what teacher-librarians do, we're that voice. And we're out there to give the teacher-librarian a sense of belonging and ... of knowing that they fit into something. (p.3)

A BCTF officer responded:

We don't just talk about the loss of classroom teachers and the need for smaller classes. We're also talking about the roles of learning specialist teachers which includes teacherlibrarians .... The [lobbying of the BCTLA] usually ends up being successful.

Every child, every school should have a school library that should be staffed by a qualified teacher-librarian .... It's not just a technical job of putting books on shelves. It's a position that needs to be a teacher working collaboratively with classroom teachers and other teachers in the school to do literacy and all [its] wide-ranging forms. And that's something that we've been fighting to preserve all this time. (p.4)

In addition to the strengthening of the political role and the two-way communications between the BCTLA and BCTF Executives, BCTLA members interviewed commended the PSA Executive for its constant conversation on their behalf, including for:

[Their] consistent, considerable, persistent, tactful, and again tactful, interaction with not just with the BCTF but with government officials.

People ... like Moira and ... Heather are very active in the BCTF and make sure that that liaison is very strong.

[They] have done a tremendous job in terms of leadership, not just within the BCTF, although that's absolutely essential to us, but also generally in terms of our reputation as professionals. (p.4)

Yet, during the fifteen years of siege on their work, there remained a passion and a strong sense of their key role in learning.

We're always organized. We know what we want. We have goals in mind. We're very big picture. ... I think we all do that as teacher-librarians.

Teacher-librarians remained very clear about their responsibilities in schools and about how to make the role work; in the words of one respondent to Ewbank's question about the advocacy role of the teacherlibrarian, there is no room for a "mole librarian":

That's what we all have to do. We have to advocate for our positions within our school communities. You have to know the parents. You have to talk to the parents. You have to constantly have dialogue with them. You have to know the kids. You have to say hello to them when the come in the hallways when they come in the school in the morning, when you talk to them in the hallways. You relate to them all the time. You can't close the door in the library and be a mole librarian. You've got to be social. (p.7)

In addition to escalated advocacy, other factors that correlate positively with the retention of teacher-librarians' positions include stakeholders' perception of the value of the school library program. Interestingly, Ewbank (2015) in her Case Study notes that:

[Researchers] Nancy Everhart and Marcia M. Mardis (2014) conducted an evaluation of a project designed to bolster stakeholders' understanding of school libraries and the profession. [They] had found that reaching out to stakeholders in an organized and thoughtful fashion while not in a crisis mode allowed stakeholders to reflect on the value of school library programs and built support for both school librarians and school library programs. (p.4)

Many teacher-librarians in BC cannot remember times that they weren't in "crisis mode." They work in two school libraries or opt for part-time or take a split load of some library and some resource support or working with English Language Learners; their flexibly scheduled portion may have been consumed by teacher prep coverage; or they have returned to the classroom. It is rare to find a full-time 
elementary teacher-librarian, strangely enough and despite the increased demands for collaborative inquiry pedagogy, for maker spaces, for teaching design skills or coding, and for support for technology and other literacies, all of which are explicitly articulated and embedded in BC's new curricular directions.

In his recent article for Canadian School Libraries (canadianschoollibraries.ca), Canada's new online school libraries publication, Richard Beaudry describes three of the issues faced by those who chose to continue as practicing TLs:

The [BCTLA] survey of 2008 refers to the difficulties of part-time work as a teacherlibrarian in BC schools: "Many respondents talked about how difficult it was for them to try to meet all of the responsibilities of a teacher-librarian on a part-time FTE appointment." ... When the mandatory ratios were stripped from the contract, many school districts replaced teacher-librarians with library technicians to save on their budgets or simply cut library time to balance their school budgets.

A second important issue was school library funding. BC has the second lowest per student funding in Canada. The direct result of this is that school libraries in some districts received little or no budgeted funds. By 2011, nearly ten years after the stripping of the collective agreement, the [BCTLA's] working and learning conditions survey of public school libraries ... indicated that fundraising was a necessity to library programs to be able to add new books to increasingly out-dated collections.

A third issue was the changing role of teacher-librarians after the ratios were stripped and budget cuts occurred. To keep their posts, many teacher-librarians, especially in elementary schools, were asked to provide prep-time coverage for other teachers in the school. This moved teacher-librarians out of the role of teaching students research and literacy skills. Their role was downgraded to simply signing out books and possibly reading a book to students if time permitted. Their role was diminished to a point that it made sense to administrators to replace or eliminate teacher-librarian positions from the school library.

(p.4)

For a short period of time, a fourth issue arose with the development of school library learning commons. The learning commons model was essentially co-opted and reduced to superficial refurbishment by some of the decision-makers as a way of saving scarce district dollars. One district presented a budget proposal to cut teacher-librarians as it was opting to "go with the learning commons model." If a space was lightly overhauled and a collection footprint reduced, teachers could be assigned to some of the role of opening the room up and supervising it; this would provide some timetable flexibility for teachers who were not teacher-librarians and eliminate costs of resources and specialist staffing. BCTLA Executive members joked darkly about how a new rug and a faux-leather couch was an ill-conceived attempt to glitz-up the old Study Hall concept. As more of the actual library learning commons have been developed and as the BCTLA and others have published more about school library learning commons, this co-opting seems to have stopped.

There are also hints of another issue; there is certainly a place for a deeper gender analysis of what was happening in schools. Often, for example, the idea of a Learning Commons was attached to the career trajectory of a technology teacher who, after all, could show students how to use tools and apps and how to Google and Google deeper. Speaking anecdotally, the answer to systemic reform, one suggested, was clearly "Apple" - and likely since then, let's add "Google." Print collections were, in the minds of some, a thing of the past. There seemed no shortage of bright young men armed with their tools ready to step into such a "learning commons" role that would be replacing the teacher-librarian, more than likely a woman whose work was defined as reading promotion and collaboration for research to develop skills for inquiry and critical thinking, as well as media and information literacies.

\section{THE CASE FOR SCHOOL LIBRARIES AND RE-INVIGORATION OF THE ROLE OF THE TEACHER-LIBRARIAN}


In a system more likely to find a teacher-librarian in an elementary school library providing prep coverage than teaching for inquiry and inspiring the love of reading deeply, it is essential to be clear about the missing possibilities. Susan Meyer, blogger for TechNotes, recently used her April post to thank school libraries and teacher-librarians:

Libraries and the innovative and imaginative librarians who run them are an invaluable part of their schools. They introduce students to a world of wisdom. They enable students to access and understand an incredible wealth of digital and traditional resources. Ultimately, they empower students to become shrewd researchers and knowledge-driven digital citizens.

We all know that libraries develop strong readers and writers. But as any librarian will tell you, it's important to back up your statements with sources. A 2013 study by the Pennsylvania School Librarians Association (PSLA) looked into what school libraries contribute to student achievement and the development of 21 st century learning skills. What they found wasn't too surprising. Reading and writing scores are consistently better for students who have a full-time certified librarian at their school over those who don't. The study also found that these benefits were even greater among minority students, economically disadvantaged students, and students with disabilities. This suggests that libraries might be one key to closing achievement gaps.

This data isn't unique to Pennsylvania, of course. In fact, 21 state studies all confirm that the presence of certified librarians in schools leads to a measurable difference in student achievement. (para.1-3)

Thank you, Susan Meyer!

No assessment of the state of school libraries, but BC school libraries in particular, is complete without alluding to the work of Ken Haycock. Haycock began his work in BC school libraries as the district administrator of school libraries with the Vancouver School District \#39 before moving to the School of Library, Archival, and Information Studies (SLAIS), now the iSchool@UBC. A 2011 study of BC school libraries confirms twenty years of American and Canadian school library research: "An easily accessed, well-funded, well-staffed, well-managed, well-stocked, integrated and heavily used school library correlated to higher student achievement" (p.3).

Haycock considers how BC's Ministry of Education utilizes data generated by provincial assessments when the findings have implications for school libraries. BC's public schools, by world standards, are high performing. Yet, years of assessments have indicated that students' information processing skills are deficient.

Throughout these assessments and interpretations, no mention was made of any role for the $T L$ or school library. Research in education and teacher-librarianship suggests that rich resources and appropriate inquiry-based learning are made relevant and cost effective when a teacher-librarian supports classroom learning outcomes through collaborative teaching. Although the library's role traditionally has been centered on information and media literacy, support for research-based projects, development of critical thinking skills and instruction on information access, there has been no mention by the Ministry of connecting the government's curriculum recommendations to library programming. Ironically, the British Columbia Ministry of Education's own policy document Developing Independent Learning: The Role of the School Library Resource Centre (1991) advocated for these roles and initiatives but has been allowed to go out of print.

In $B C$, as elsewhere, it would seem that roles and responsibilities traditionally undertaken collaboratively by the teacher-librarian have been relegated to classroom teachers alone through design or neglect. As the recommendations remain the same year after year, it is not a stretch to conclude that classroom teachers are not receiving the training and support they need to carry out mandated initiatives, if indeed they are able to do so on their own. The research suggests that the decline in media and information literacies and reading skills can best be addressed through a collaborative effort between teachers and qualified teacherlibrarians, as this study demonstrates. (p.5) 
For Dianne Oberg (2017), in writing about the broader Canadian picture of provincial educational jurisdictions and their ignoring large-scale assessment data that could open the doors of more of the country's school libraries, the picture is the same:

When provincial, national, or international learning assessments are analyzed, the areas of concern that emerge are frequently library-related, particularly in the realm of information literacy practices: formulating questions, identifying appropriate sources of information, locating information, distinguishing between relevant and irrelevant information. While in parts of Canada we are cutting back on school libraries, in parts of Europe they are being supported as a force for educational reform. (p.1)

In short, despite evidence that investment in school library programs is a sound educational practice that benefits students' academic and social development in many ways, where the evidence suggests that the BC Ministry of Education and other policy-makers across Canada should provide support for the key role of the school library through funding, clear inscription in curriculum, legislation, and contractual agreements, inclusion of teacher-librarians and school libraries in curriculum, curriculum development, and resource selection, as well as development of clear policies and mandates for hiring qualified (or qualifying) teacher-librarians and funding school libraries in school districts, to date they have not.

Marlene Asselin and Ray Doiron (2008) assess how the foundations of education have been dramatically transformed by rapid change in communication and information technologies. They propose a new and transformative pedagogy for the "new" learners, enabling them to participate successfully in their various social, economic, and cultural communities around the world and beyond K-12 schooling; such schooling requires firm foundations both in traditional literacy and in the empowering capacity of being able to use effectively the skills and practices of a number of multi-modal literacies, skills like:

- Technology literacy, including acquiring skills in searching; using soft- and hardware, as well as social media; "reading the landscape" of the Internet; using skills for word and writing processes, social media communications, and format and application integration with writing and publishing.

- Inquiry and problem-solving, including recognizing the need for more information; asking good questions; creating new knowledge from information they have accessed and selected; understanding the structures and schemata of information; synthesizing, creating, and sharing information as new knowledge.

- Critical literacy, including learning how to assess information for power relationships, authenticity, capacity to influence; matching tools to their learning needs; understanding their roles in both global and social contexts; and functioning effectively in a democratic society.

- Ethics and social responsibility, including using information and producing new knowledge ethically; valuing fair, open, respectful, legal, and equitable access to information and socially constructed knowledge; and understanding issues of privacy, copyright, and intellectual property.

- Creativity and representation, including honing skills of the multi-literacies and technologies, new and emerging, for constructing, sharing, and representing new knowledge; incorporating creativity and balance in presentation, design, and communications. (pp. 8-9)

Allan Luke, a participant in the New London Group from which emerged The Pedagogy of Multiliteracies (1995), addressed academics in a 2015 Disruptive Discourse Lecture at the invitation of the UBC Faculty of Education; he discussed the failure of this pedagogy - it has a finite life, the gaps are exposed, the discourse fragmented, and the rifts are not going to be closed. "We need to create a generative model," Luke suggests. From notes:

Slow down, I thought. Just slow down. The work we do, as described in the event blurb, to focus on "creative and critical engagement with new technologies as means for expression and representation with a strong focus on student 'voice,' identity and place of students and communities who have been historically marginalized in print-based, industrial-era education" has been overtaken by a new and more ominous reality, one that has invoked "moral panic" - how and what do we teach that will prepare our students for the world laid 
bare by one ordinary man named Edward Snowden? No discussions of the New London group could have predicted "Hacktivism, cyber-bullying, Wikileaks, Gamergate, Google vs the Great Firewall of China, the Internet of Things, and a host of other new social, economic and cultural phenomena," a world where the traditional "patching in" of add-on lessons about cyberbullying, for example, is simply not enough.

Did I hear that right? "Education isn't what it used to be - except in high school." Although these words are not his, Luke placed ultimate and significant value on the public school system but I didn't get the sense that he understood how particularly besieged we are here in $B C$ and how those with the mandate to "reform" our schools are stripping them instead of building in the capacity to explore, assess, redesign, and implement meaningful reform from the ground up; teachers live in fear of the neo-liberal education agenda ... but I wasn't sure we in schools would be able to look to academe for support in driving change or even doing battle with the academics for a place and a voice at the reform table. The work of schools has been intensified, the workers demeaned and de-professionalized, the time for thoughtful consideration of reform and direction deliberately eroded. (Ekdahl, 2015 June 5)

His talk, well before recent political developments, was entitled "Education After Snowden: Teaching and Learning About the New Information Order." The urgency for reconsideration of the place of school libraries in the learning equation in $\mathrm{BC}$ schools has taken on new and dramatically enhanced proportions since Luke began the list of issues for which most young BC students are not adequately prepared. In the "host of other new social, economic and cultural phenomena" that our students face, he could make no mention of "fake news," grand-scale international political interference, Big Data, the dark net and the deep net, jihadist and other vile lurings, and the shocking global rise and/or resurgence of right-wing or ultra-conservative politics. While BC students are more likely to be on the winning side of the issues around marginalization that Luke so eloquently identified, they are poorly equipped for this world in a "moral panic." Can we continue to face up to our responsibility to these students by offering the add-on lessons on cyberbullying?

\section{THE PROMISE AND PROCESSES OF RESTORATION AND RENAISSANCE: A TIME FOR HOPE IN SCHOOL LIBRARIES?}

Lambert finishes the tale of a very specific and political teachers' fifteen-year struggle to retain basic rights in a democratic society by shifting from home base back to the new global reality in which we teachers are "teaching after Snowden":

Because of the commitment of teachers, their tenacity, and willingness to pool resources and pursue this case to Canada's Supreme Court, in the Coquitlam school district where I live, $100+$ new teachers are supporting students right now, with more to be hired this fall. It's a start.

And crumbling institutions of democracy in a Trump era? Three critical institutions - our judicial system, our union rights, and public education - are strong and getting stronger. Our next task is to hold individuals and politicians to account, and strengthen our electoral political system.

Clearly the arc bends increasingly toward workplace Justice. (Madame Justice Rosa Abella, Saskatchewan Federation of Labour v Saskatchewan, 2015, para 1, as cited in Lambert, p.8).

Lambert had begun to capture the effects of significant change in BC's public education system. For teacher-librarians, even as their role and teaching efficacy had been eviscerated by the ill-conceived and now-illegal cuts, even as the place of the school library in relation to classroom learning felt as though it had been assigned "second-class" status, the need for the teaching of skills for media and information literacies, critical thinking, and information source evaluation and other aspects of what might be considered the school library program "curriculum" has escalated. Suddenly and remarkably, our youngest teachers are, for the first time in BC's teaching memory, the same ones who were teacher candidates last year, now working alongside those who were five years into what had become a seven- 
year trek as a "teacher-teaching-on-call" (TTOC) to a continuing position and with retirees happily returning to work as TTOCs; in some districts and in some particular areas, restoration of staffing would be making a real difference and it couldn't be more apparent.

For teacher-librarians, the collective agreement clause pertaining to non-enrolling staffing ratios specified one teacher-librarian for every 702 students, a number that was bargained for and became effective in 1999 in a special closed-door decision made by then Premier Glen Clark of the New Democratic Party and BCTF President Kit Krieger. The "Restored Language" includes:

9.F.3 Non-enrolling staffing ratios

(a) Employee staffing ratios in each category shall not decrease below the number reported in the 1997/98 Ministry form 1530 for this District, as follows:

(i) Teacher-Librarians: 1:927.3

(ii) Teacher-Counsellors: 1:535

(iii) Learning Assistance Teachers: 1:801

(iv) Special Education Resource Teachers: 1:232

(v) Support for ESL Students: 1:64.7

(b) Teacher-Librarians

(i) Effective 1998 July 01, teacher-librarians shall be provided on a minimum pro-rated basis of teacher-librarians to students in the ratio of 1:921.

(ii) Effective 1999 July 01, teacher-librarians shall be provided on a minimum pro-rated basis of at least one teacher-librarian to seven hundred two (702) students. (VTF)

Showing change over time, the "new" ratio in the provincial and local matters collective agreement had been reduced by 225 students.

\section{CONCLUSION}

The dust hasn't settled yet. At the time of writing, school timetables are being set and postings, prepared. Much of what has been "collected" in the way of information that follows is anecdotal and has been gathered by email and other personal communications.

Perhaps the first indicator of a dramatic sea-change in the field of school libraries following from the November 2016 Supreme Court of Canada's finding for the BCTF was the sudden increase in applications to enrol in the teacher-librarian diploma program at the University of British Columbia and the sudden awareness of an immediate need for instructors for the program's newly-re-designed courses. There had been few if any warnings of a tsunami!

In personal email communications, Dr. Marlene Asselin explains how UBC is responding to the increased demand.

The UBC Teacher Librarian (LIBE) program has approximately 100 new admitted students to the summer and fall 2017 courses. We recognize in these above average numbers a need to provide the full array of the 10 course LIBE diploma program. We are still discussing how to proceed, as we need to support these students through their studies, provide full sections of courses and give them the best service and learning experience. For example, cohort models (online and on site) enable us to structure students' diploma (certificate), can eliminate the rush to register in everything, and enable the spread of demand across several courses/sections. UBC sees this increased demand for trained teacher-librarians as an opportunity to demonstrate their commitment to quality public education in British Columbia. (2017.05.27)

In some school districts, nearly all the teacher-librarian positions had been eliminated over the fifteen years. More than one district has reported needing to find 45 TLs! For such districts, one solution, derived in consultation with the UBC Faculty of Education's Language \& Literacy Department and various district management personnel, focuses on the recruiting of good, well-experienced classroom 
teachers. UBC offered to implement the "cohort" approach to training them in partnerships with several districts and, happily for the teachers, the proposals have been accepted.

Other districts have not identified a need for more teacher-librarian staffing as their priority; in fact, in these districts, the staffing situation for teacher-librarians is quite the opposite. The ratio, intended as a minimum guideline, represents conditions which, usually averaged in consultation with the districts' teacher-librarians in the past, was never fully realized across the district. In other words, while 1:702 represents a situation that needs to be "restored" to better conditions due to the elimination of, in one of these districts, more than 15 FTEs of TL time, some districts claim they had retained enough teacherlibrarian FTEs to comply with the contract guidelines and would be restoring nothing. Others are "rationalizing" cuts to non-enrolling staffing rather than restoring what was taken as they presently have a district-averaged ratio less than 1:702. In one district, despite practices of school-based staffing decisions, administrators are being warned to comply with an order not to vary the staffing of school libraries.

Another persistent issue emerges from the shifted and diminished role is the length of time; fifteen years is a long time in which teacher-librarians' capacity to deliver strong and dynamic programs has been increasingly eroded. One respondent to a recent informal survey of practitioner-instructors in the UBC Teacher-Librarian diploma program describes the problem:

Administrators and staff [need to be educated about] what teacher-librarians can do. Especially administrators .... Most of the principals who were in schools before the ratios were cut are retired and the rest [are] close to retirement. Many principals, especially in the elementary schools, see the teacher-librarian role as primarily one of offering prep time and book exchanges since this is how they dealt with the school libraries after the ratios were cut. School libraries have been changing. [Teacher-librarians] see their own role as being very different than it was sixteen years ago.

Teacher-librarians will need to move quickly to present to administrators and staff the kind of work that they can do in the schools. In this district, the teacher-librarians are preparing a presentation to the Board in the new school year to offer an overview of the different tools at their disposal, the different work spaces that are offered, and the ways they work with teachers and students to implement the new curriculum. (Email, 2017.05014)

In addition, the respondent continues, many of the "seasoned" teacher-librarians who do remember the times before cuts to ratios are also preparing to retire, taking with them the wealth of knowledge that has sustained and inspired remarkable programs and gains in the field. There is a real need for systems of mentoring to be put in place as the new ones complete their programs.

Local union officers do offer support for their teacher-librarian members while consoling them, where necessary, to the immediate realities of the various interpretations of what 1:702 will look like in their districts. Vancouver Secondary Teachers' Association President and recently elected Member-atLarge to the BCTF Executive Rory Brown, by personal email, distinguishes between the need to comply with contract language and the desire to provide better service delivery to students; he offers assurances of support to Vancouver (and provincial) teacher-librarians:

The union will continue unrelentingly to enforce the terms of the contract including the district ratios. On a separate but related note, the union will also lobby and advocate for increases in education funding that would allow increases to TL staffing in excess of the district ratio so that children have access to an open, well-funded library in each school.

This is important; vital, even. (2017.05.27)

Well, that ends the "season" of this eventful docudrama. Hope for some that there could be real restoration and a renaissance for school libraries in BC in the next school year has dwindled. There is a sense of futility that remains in the air; the sense of victory, gone for many. Stay tuned for more details in Los Angeles, and hopefully more dramatic and significant unfolding of the plotlines in the fall.

\section{REFERENCES}

Asselin, M. (2017). Personal email communications. 
Asselin, M., \& Doiron, R. (2008) Towards a transformative pedagogy for school libraries 2.0. School Libraries Worldwide, 14(2), 1-18.

Beaudry, R. (2017). BC Teacher-Librarians: Looking back and moving forward. Canadian School Libraries Journal,1(1). http://journal.canadianschoollibraries.ca/bc-teacher-librarians/

British Columbia Teachers' Federation (BCTF) Research Division. (2016). BCTF Education Funding Brief to the Select Standing Committee on Finance and Government Services. Vancouver, BC: BCTF. https://bctf.ca/uploadedFiles/Public/Publications/Briefs/ EducationFundingBrief2016.pdf

Brown, Rory. (2017). Personal email communications.

Croll, S. (2014). The future of school libraries: Vibrant spaces or dead coral reefs? Teacher Newsmagazine, 26(6). https://bctf.ca/publications/NewsmagArticle.aspx?id=33065

Daly, H. (2012). Personal communication. In Ewbank, A. (2015). Union-active school librarians and school library advocacy: A modified case student of the British Columbia Teacher-Librarians' Association and the British Columbia Teachers' Federation. School Library Research, 18, 1-23. http://www.ala.org/aasl/sites/ala.org.aasl/files/content/aaslpubsandjournals/slr/vol18/SLR_Union ActiveSchoolLib_V18.pdf

Everhart, N., \& Mardis, M. (2015). What do stakeholders know about school library programs? Results of a focus group evaluation. School Library Research, 17. http://www.ala.org/aasl/sites/ala.org.aasl/ files/content/aaslpubsandjournals/slr/vol17/SLR_StakeholdersKnow_V17.pdf

Ewbank, A. (2015). Union-active school librarians and school library advocacy: A modified case student of the British Columbia Teacher-Librarians' Association and the British Columbia Teachers' Federation. School Library Research, 18, http://www.ala.org/aasl/sites/ala.org.aasl/files/content/aaslpubsandjournals/slr/vol17/SLR_Stakeh oldersKnow_V17.pdf

Ewbank, A., \& Kwon, J. I. (2013). The role of teacher union in school library advocacy: A case study of the British Columbia Teacher-Librarians' Association and the British Columbia Teachers' Federation - Preliminary findings and recommendations. Tempe, AZ: Arizona State University.

Haycock, K. (2002). A review of the role of the teacher-librarian and school library resource centre in School District \#39. Vancouver, BC. http://www.vsb.bc.ca/sites/default/files/ 10Nov05_op_commIII_item3.pdf

Haycock, K. (2011). Connecting British Columbia (Canada) school libraries and student achievement: A comparison of higher and lower performing schools with similar overall funding. School Libraries Worldwide, 17(1), 37-50.

Hemingway, A. (2016 Aug 24). What's the real story behind BC's education funding crisis? Policy Note. Vancouver, BC: Canadian Centre for Policy Alternatives (CCPA). https://www.policyalternatives.ca/sites/default/files/uploads/publications/BC\%20Office/2016/08/ ccpa-bc_Kto12EducationFunding_web.pdf

Kilian, C. (2016). Christy Clark just got laughed out of the Supreme Court of Canada. The Tyee. Vancouver, BC: thetyee.ca. https://thetyee.ca/Opinion/2016/11/11/Clark-Supreme-CourtTeachers/.

Klein, S., \& Ivanova, I. (2017, April 28). BC's child poverty rate: Don't cherry-pick the numbers. Policy Note. Vancouver, BC: Canadian Centre for Policy Alternatives (CCPA). http://www.policynote.ca/bcs-child-poverty-rate-dont-cherry-pick-the-numbers/

Lambert, S. (2017, March 7). Public education under BC's Liberals: Fifteen years of willful neglect. $B C$ Studies: The British Columbian Quarterly. https://bcstudies.com/?q=blog/public-educationunder-bc's-liberals-fifteen-years-willful-neglect

Levin, D. (2017, Jan 13). British Columbia: The 'Wild West' of Canadian political cash. The New York Times. https://www.nytimes.com/2017/01/13/world/canada/british-columbia-christy-clark.html

Luke, Allan. (2015). Education after Snowden: Teaching and learning about the new information order. Vancouver, BC: UBC Language and Literacy Education. https://www.youtube.com/ playlist?list=PLoA5fmxjwBDgwlnnk0GQlEh1Ga3QhmvYY 
Luke, Allan. (2015, May 6). Education after Snowden: Teaching and learning about the new information order. Disruptive Discourse Lecture Series. Vancouver, BC: UBC Faculty of Education. In M. Ekdahl, An insider looks at the multiliteracies (20 years after the advent): Teaching PostSnowden.

Meyer, S. (2017, April 12). School libraries - more important than ever. TechNotes blog. TCEA. https://www.tcea.org/blog/importance-of-school-libraries/

Oberg, D. (2017). Ignoring the evidence: Another decade of decline for school libraries. Education Canada, 57(1). http://www.cea-ace.ca/education-canada/article/ignoring-evidence-anotherdecade-decline-school-libraries

Smith, C. (2016). Supreme Court of Canada ruling in favour of BCTF raises important question about B.C. Court of Appeal. Georgia Straight. Vancouver, BC. http://www.straight.com/news/826966/ supreme-court-canada-ruling-favour-bctf-raises-important-question-about-bc-court-appeal

Vancouver Teachers' Federation (VTF) Collective Agreement. (2013). Vancouver, BC: Vancouver School Board, Vancouver Elementary and Secondary Teachers' Associations.

Zussman, R. (2016, Nov. 10). Timeline: Nearly 15 years of court battles between province and BCTF. Supreme Court of Canada rules in favour of BC teachers, ending a fight that started in 2002. CBC News. http://www.cbc.ca/news/canada/british-columbia/timeline-nearly-15-years-of-court-battlesbetween-province-and-bctf-1.3846338 